\title{
THE NATIONAL UNEMPLOYED WORKERS' MOVEMENT, 1921-36
}

\author{
A RE-APPRAISAL
}

Between the wars, the response of the British Labour Party and Trades Union Congress to the problem of the unemployed was extremely limited. Committed to gradualist philosophies, the leaders of the labour movement were unwilling to attempt genuine socialist remedies in office, and, in opposition, to provide a militant leadership for the protest movement. The National Unemployed Workers' Movement, begun in 1921 and not finally dissolved until after the outbreak of the Second World War, was the only body which attempted to mobilise unemployed discontent. After 1926, the Labour Party Executive and the General Council of the TUC consistently refused to have any contact with this organisation on the grounds that, like the National Minority Movement and the later Rank-and-File Movement, the NUWM was merely a subsidiary of the British Communist Party. This article is an attempt to show that by a process of induction the Labour leaders branded the unemployed movement as a whole on the basis of the known Communist allegiance of a number of its leaders, and to demonstrate that they allowed themselves to become so sidetracked by the issue of whether or not the NUWM was a Communist front that their own efforts on behalf of the unemployed suffered in consequence. ${ }^{1}$

With the collapse of the post-war boom in the summer of 1920 unemployment suddenly became one of the most important issues of the day. The numbers out of work rose from 274,000 in September 1920 to more than 500,000 by the end of October. In January 1921 unemployment

1 In this and similar areas historians have often accepted the position of the official labour movement without much question. R. Martin, Communism and the British Trade Unions 1924-1933. A Study of the National Minority Movement (Oxford, 1969), p. v, has noted that "The threat posed by the 'Red Machine' to the British trade union movement has been a permanent theme in both academic and popular discussion of British labour history. Yet the discussion has been stronger on invective than analysis". J. Stevenson and Ch. Cook, The Slump. Society and Politics during the Depression (London, 1977), ch. 9, devote a section to the origins of the NUWM. But even their otherwise excellent book does not deal as fully with the subject as this article attempts to. 
passed the million mark, and, except for a few weeks in 1926, did not fall below this figure again until 1940. It was the policy of successive governments during this time to try to maintain the unemployed at subsistence level by donations from public funds, in the hope that things would soon take a turn for the better. In Britain the new economic theories propagated by Keynes and a small number of others found little support in government circles. Throughout these years the Treasury view was basically that expressed by Winston Churchill, then Chancellor of the Exchequer, in the House of Commons in April 1929, namely, that "little additional employment, and no permanent additional employment, can, in fact, and as a general rule, be created by State borrowing and State expenditure."2

The Labour Governments of 1924 and 1929-31 accepted such a view. In attempting to deal with unemployment, Labour followed the orthodox policies of its Conservative predecessors with only minor modifications. While the Zinoviev Letter provided the excuse in 1924, after the defeat of 1931 the new leaders were able to apportion a large part of the blame for the failings of the Second Labour Government on the Liberals, and also on the "traitors", Ramsay MacDonald, J. H. Thomas and supporters. In neither case was there an adequate examination of the real reasons for the Labour Party's failure in office. Even after 1931 the party conference remained satisfied for the most part with the view that the Labour Government had done its best under difficult circumstances, and that the unemployed, along with the rest of the nation, must wait until the next election, in order to return a new Labour Government with a working majority. Until then party members should do nothing to damage Labour's electoral chances: the left wing must accept that the leadership could undertake no activities that did not fall within the strict framework of parliamentary democracy.

Similarly, although trade-union membership was falling steadily, the TUC was still primarily concerned with the employed, and devoted little attention to those out of work. ${ }^{3}$ The 1930 Congress had passed a resolution regretting the inadequacy of the efforts of the Labour Government to deal effectively with unemployment, but recognising that it was a minority government, "prevented from operating effective Socialistic measures for the only solution of unemployment". ${ }^{4}$ After the defeat of 1931, the trade-

2 House of Commons Debates, 15 April 1929.

3 Trade-union membership fell from 5.5 million in 1925 to well under 4.5 million in 1932 and 1933. G. D. H. Cole and R. Postgate, The Common People, 1746-1946 (London, 1964), pp. 596-97.

4 Report of the 62nd Annual Trades Union Congress, 1930, pp. 287-88. R. Skidelsky, Politicians and the Slump. The Labour Government of 1929-1931 (London, 1967), has 
union leaders would go no further than their political counterparts, and subsequent Congresses, in spite of the strenuous efforts of a few, endorsed this approach by large majorities. The trade-union objection to the treatment of the unemployed was thus confined to the same well-meaning phrases with which the Labour Party conference tried to appease its conscience. At Bristol in 1931, for example, the TUC carried a resolution declaring its "strenuous and unremitting opposition to the proposals to reduce the present meagre [unemployment] benefits", while at Newcastle the following year Congress recorded its "emphatic protest" and "strongly" condemned the Government's policy in regard to those out of work..$^{5}$

It was not until 1932, by which time the problem of the unemployed had been with the labour movement for more than a decade, that the General Council began to consider a scheme for "unemployed associations", in an attempt to ensure that at least some of those who lost their employment were given the opportunity to keep in touch with their unions and workmates. Even then, however, the attempt appears to have been half-hearted. The organisation of these associations was left entirely to local trades councils, who could, if they wished, take steps to form such a body in their district. For its part the Labour Party decided merely to "leave responsibility in the matter [of organising the unemployed] to the General Council". ${ }^{6}$ No further support or encouragement was given, either to the TUC to press ahead with this work, or to the rank and file to join such associations if they fell out of work. By the time of the Weymouth TUC in 1934 , the number of unemployed associations in existence was 123 , with a membership of about fifty thousand, and the peak was reached soon after this. No national organisation was ever undertaken: the only attempt at official guidance came in 1935 , by which time recovery was on the way, with the promise by the General Council to pay the expenses of Trades Council Federation officials who visited the associations within their areas to "stimulate and advise" them. ${ }^{7}$

In 1934 a committee appointed by the General Council to consider "the whole of the services" provided for the unemployed, and "to report on what extensions or alterations, if any, are necessary", reached the con-

demonstrated that, even if it had been in a majority, Labour would not have followed a substantially different course from the one it chose, and that the Liberals, therefore, must not be blamed for Labour's failure to introduce radical measures to deal with the problem of unemployment.

5 Report of the 63rd Annual Trades Union Congress, 1931, p. 342; Report of the 64th Annual Trades Union Congress, 1932, p. 268.

6 Labour Party, Report of the 33rd Annual Conference, 1933, p. 30.

7 Report of the 66th Annual Trades Union Congress, 1934, p. 123; Report of the 67th Annual Trades Union Congress, 1935, p. 122. 
clusion that the associations "performed an extremely useful purpose in protecting their members". It urged that there should be "no curtailment" of efforts to form new unemployed associations, and recommended also that affiliated unions with large numbers of unemployed members should "investigate the possibility of providing facilities whereby such members may maintain their employability". 8 Nothing came of this, however, and it is difficult to avoid the conclusion that the General Council was to some extent deluding itself about the success of its efforts. The report to the 1936 Congress estimated that, of 130 unemployed associations in operation, approaching fifty were situated in the Lancashire and Cheshire region. It was reported that a sub-federation of unemployed associations had been formed, which was attached to the local Federation of Trades and Labour Councils. ${ }^{9}$ If this was the case, however, there is no evidence to show that the formation and encouragement of such organisations constituted an important part of the work of the Lancashire and Cheshire Federation. It would appear that, where associations were established, they remained small bodies, of which no records were kept or remain - unlike other efforts on behalf of the unemployed. Unemployed associations were reported to have been established at Rochdale and Heywood in 1932, but there were no reports of similar efforts in Manchester or Salford, while at Oldham the local trades council was reported to have decided against the formation of such an organisation. ${ }^{10}$

The labour movement's response to the problem of the unemployed was insignificant compared with that of a voluntary nature, although even here there was a considerable interval between the appearance of unemployment and the first real efforts to help those affected. In 1927 an educational settlement was founded by the Society of Friends at Trealaw in the Rhondda. In the same year members of the Workers' Educational Association established a club at Lincoln where the unemployed were offered warmth, shelter and fellowship, the chance to relieve their boredom by repairing shoes and furniture for themselves and others, and to grow vegetables for their own use. These were the beginnings of what was to become an extensive movement. By September 1931 some 120 voluntary schemes were in operation, all owing their existence to local

${ }^{8}$ Report of the 67th Annual TUC, pp. 123-24, 128; Social Service Review, published by the National Council of Social Service, September 1935.

9 Report of the 68th Annual Trades Union Congress, 1936, p. 56; see also Report of the 69st Annual Trades Union Congress, 1937, p. 116.

10 Rochdale Observer, 13 February 1932; Heywood Advertiser, 18 August 1933; Oldham Evening Chronicle, 9 and 25 March 1932. 
initiative. Thereafter, the National Council of Social Service undertook overall responsibility for the movement, and by 1936 more than one thousand occupational centres for men, and over three hundred for women, were in being, with a total membership of more than $150,000 .^{11}$

Such centres met with a good deal of opposition from the Labour leaders, and, except in a measure in Scotland, they did not obtain the official backing of the Labour Party and the TUC. A large body of tradeunion opinion viewed all efforts to engage men and women in handicraft work by voluntary means with great suspicion, fearing that the centres would produce semi-trained craftsmen who could be used to undercut existing wage-rates. ${ }^{12}$ The labour movement also objected to the centres on the ground that this kind of work was merely palliative, and was made an excuse by the National Government not to deal with the real causes of unemployment. So it was, but the Labour Government's record and the labour movement's own efforts hardly placed them in a position to criticise the voluntary response. Although the WEA provided a number of educational classes for the unemployed with TUC approval, the objections raised by the General Council to the occupational centres meant that anything other than the provision of games, lectures and lantern shows was frowned upon.

For different reasons, there was also no place for the NUWM, with its provocative "call to action", in the philosophy of the Labour leaders in the inter-war years, and the NUWM had little chance of being allowed to attach itself to the official labour movement as it wished. Throughout the inter-war years, relations between the British labour movement and the CPGB were determined by the Labour leaders' mistrust of the others' motives. The CPGB was refused affiliation to the Labour Party on several occasions during these years, and after 1924 individual Communists were ineligible for Labour Party membership. In the 1930's, after Hitler's coming to power, when the Labour leaders were under some pressure from the rank and file to modify their attitude to the Communists, the Labour Party Executive and the TUC General Council found it necessary to issue a number of circulars and pamphlets, reminding the movement of the danger of permitting Communist infiltration. Thus in March 1933 the

11 See my article "The Voluntary Occupational Centre Movement, 1932-39", in: Journal of Contemporary History, VI (1971), No 3, p. 156-71.

12 Report of the 65th Annual Trades Union Congress, 1933, p. 120; Report of the 66th Annual TUC, pp. 125-27. In some districts "a good deal of pressure" was placed on unemployed trade unionists not to join the centres. H. A. Mess, Voluntary Social Services since 1918 (London, 1948), pp. 51-52. 
National Joint Council published Democracy v. Dictatorship, a few days after the CPGB had invited the Labour Party Executive to consider plans for a United Front. In June of the same year, the Labour Party published a pamphlet entitled The Communist Solar System, while in early 1936, following a further application for affiliation from the CPGB, another statement, British Labour and Communism, was put out. ${ }^{13}$

While this was the attitude of the leadership, however, many rank-andfile members of the labour movement held different opinions. Stirred by events in Germany, many local Labour parties, for example, were ready to join the call for a United Front. Objections were also raised to the leaders' tendency to compare Communism with Fascism. At the 1933 Labour Party conference, Ellen Wilkinson argued that the pamphlet The Communist Solar System was a "magnificent advertisement of the energy and drive of the Communist Party in this country". ${ }^{14}$ Similarly, in 1936, an Edinburgh delegate voiced the opinion that the circular British Labour and Communism "paints the Communists so black that even Hitler must feel rather envious". Nevertheless, the majority of delegates sided with the Executive. When H. E. Clay, of the Transport Workers, stated that he felt the United Front proposals were "really an attempt to provide a platform for the Communist Party that it cannot otherwise get", there were many who agreed with his sentiments, and there was, indeed, a good deal of truth in them. ${ }^{15}$

For several months in 1924 and 1925, a Joint Advisory Council had been established between the National Unemployed Workers' Committee Movement (as the unemployed movement was known until 1929) and the TUC General Council. This was at a time when the latter was exhibiting a strong leftward trend. Later on, relations were broken off by the unemployed, who found themselves unable to persuade the TUC to join in some of their more militant demonstrations. From this date onwards, the Labour leaders viewed the unemployed movement with some suspicion. The report to the 1929 TUC declared that it "pretends to be an independent movement having no connection with Communism", and referred to a speech by the National Organiser of the NUWM, Wal Hannington, quoted in Pravda, in which he stated the CPGB had considerably influenced the unemployed in Britain through the NUWM.16

${ }^{13}$ For the latter see Labour Party, Report of the 36th Annual Conference, 1936, pp. 296-300.

14 Report of the 33rd Annual Conference, p. 221.

15 Report of the 36th Annual Conference, pp. 208, 256.

16 Report of the 61st Annual Trades Union Congress, 1929, p. 171. 
When, in February 1930, the Labour Party Executive issued the first of its so-called "Black Circulars", declaring a number of organisations stated to be under Communist control ineligible for membership, the NUWM was among the bodies listed. ${ }^{17}$

In 1931, and again in the two following years, the NUWM requested that deputations be allowed to address the TUC, but this was refused. At Bristol in 1931, J. R. Leslie, Chairman of the General Purposes Committee, told delegates that the Committee had refused because it felt "no useful purpose could be served" by admitting the deputation. Congress and the General Council were "fully alive to the position", and were "endeavouring to deal with the vital problem of unemployment continuously and constructively in the interests of both employed and unemployed". ${ }^{18}$ In 1933, after representatives of TUC unemployed associations had been allowed to speak, one delegate, Frank Rowland, expressed the opinion that Congress was "attempting to sort the sheep from the goats. They were going to have the respectable unemployed, but not the non-respectable unemployed". Another delegate thought that the NUWM's "national hunger march" of 1932 had done "more to focus public attention upon unemployment and what it meant than anything the General Council had done in regard to the matter". In a speech similar to one he had made at the same point at the 1932 Congress, however, General Secretary Walter Citrine helped quash the proposal to admit the NUWM by repeating the leadership's view that it was "unquestionably a subsidiary of the Communist Party". 19

Likewise, the official Labour leaders were not prepared to support the Hunger Marches organised by the NUWM, of which there were six in the inter-war years, in 1922, 1929, 1930, 1932, 1934 and 1936. As a result, it is the Jarrow March which is best remembered of all such marches which took place in these years. Organised by the local town council, and timed to take place a few days ahead of the NUWM March of 1936, the Jarrow March had the official backing of the Labour Party and the TUC, and thus received considerably more publicity, and favourable publicity at that, than anything organised by the NUWM. Yet the Jarrow March involved only two hundred men, while about a thousand took part on each of the NUWM marches. The police records of the 1936 NUWM March indicate that over thirteen hundred men took part, and that there was in addition

\footnotetext{
17 Labour Party, Report of the 30th Annual Conference, 1930, p. 29. Organisations proscribed included the National Minority Movement and Friends of Soviet Russia.

18 Report of the 63rd Annual TUC, pp. 75-76.

19 Report of the 64th Annual TUC, pp. 298-305; Report of the 65th Annual TUC, pp. 270-74.
} 
a contingent of forty-three unemployed women. ${ }^{20}$ In spite of instructions to the contrary, a large number of trade unionists gave their support as individuals to the NUWM marches, and local Labour parties often provided overnight accommodation or food and drink for the contingents en route.

There is evidence to suggest, however, that the NUWM was not entirely comparable with the Minority Movement, and other such organisations, but was to a much greater extent independent of the CPGB. While the leaders of the unemployed movement, both at local and at a national level, were often party members, even more striking is the fact that many were also unemployed skilled engineers. Wal Hannington was a former engineer; so was Percy Haye, the first Secretary, along with Tom Mann, the movement's Treasurer, and Harry McShane, leader in Scotland. The unemployed movement was strongest in engineering centres, such as the Clyde, Coventry and South-East Lancashire. ${ }^{21}$

The NUWM, in fact, grew out of the wartime Shop Stewards' and Workers' Committee Movement, which was also centred on the engineering industry. Although in the decades before 1914 there had been militant sections within the engineering union, ${ }^{22}$ as a result of wartime experiences and the activities of shop-stewrds by 1918 the majority of engineering workers had become politically conscious. At the end of the war, union recognition of the role of shop-stewards, and the removal of restrictions on trade unions, meant that there was no longer any need for the unofficial movement. To forestall its total collapse, there was an attempt to bring together the rank-and-file organisations in different industries, and in April 1921, at a conference at Sheffield, the Shop Stewards' Movement was renamed the National Workers' Committee Movement. Although the miners' reform committees joined, they were the only sizeable non-engin-

20 National Hunger March, 1936, Metropolitan Police Records, Mepol 2, 3091. At the same time, a third group of marchers were also converging on London, a contingent of 140 blind unemployed organised by the National League of the Blind, but this is also usually overlooked. National League of the Blind: March to London, 1936, Home Office Papers 45/16545, Public Record Office.

21 Almost all the men whom the author interviewed in the South-East Lancashire region were former engineers. Mr Edmund Frow, co-editor with M. Katanka of 1868 - Year of the Unions, and until 1971 District Secretary of the engineering union in Manchester, was one of the leaders of the Salford Branch of the NUWM in the 1930's. I am indebted to Mr Frow for many of the suggestions contained in this article, and for making available to me much of the NUWM material on which it is based.

22 J. B. Jefferys, The Story of the Engineers 1800-1945 (London, 1945). 
eering group to do so, and the new body was "dominated by engineers in every respect". 23

The historian of the Shop Stewards' Movement, Branko Pribićević, has noted that "Unemployed Workers' Committees also became a form of activity in 1921-22."24 The slump of 1920 and 1921 quickly affected the engineering industry: in December 1920 there were 19,926 unemployed union members, but by July of the following year this number had leapt to 114,000 . Many of the first victims of unemployment were shop-stewards from the Clyde, London and elsewhere, who had been involved in the wartime movement, and who now lost their jobs as employers took the opportunity provided by the depression to weed out militants from the factories. These were men with an inclination and talent for leadership, as proved by their wartime efforts; above all they were politically conscious. ${ }^{25}$

The first examples of organisation among the unemployed were found in the formation of Unemployed Ex-Servicemen's Organisations, which began to appear in the autumn and early winter of 1920. In October 1920, a London District Council of Unemployed was established following a meeting of delegates representing the ex-servicemen's organisations in eleven London boroughs. This had Wal Hannington as organiser, Percy Haye as secretary, and Jack Holt, another engineer, as chairman. ${ }^{26}$ In April 1921, a further conference was held at the International Socialist Club in Hoxton, attended by more than fifty delegates representing towns throughout England and Wales, at which the National Unemployed Workers' Committee Movement was brought into being.

Thus it is in no way correct to say merely that the Communist Party "founded" the unemployed movement, ${ }^{27}$ since it was begun at the same time as the CPGB was being established. Henry Pelling is nearer the truth when he says that

The unofficial shop stewards movement, which had been in decline since the end of the war, was finally broken by the heavy unemployment of the 1920 s, although some of its leaders adapted themselves to the situation and set up what they called the National Unemployed Workers Committee Movement. ${ }^{28}$

${ }^{23}$ B. Pribićević, The Shop Stewards' Movement and Workers' Control (Oxford, 1959), pp. 104-05; see also Martin, Communism and the British Trade Unions, op. cit.

${ }_{24}$ Pribicevic, The Shop Stewards' Movement and Workers' Control, p. 107.

25 Jefferys, The Story of the Engineers, op. cit., p. 218.

${ }^{26}$ Hannington had been a prominent shop-steward in the later part of the war, and had joined the St Pancras Ex-Servicemen's Organisation in September 1920, soon after losing his job.

27 Cole and Postgate, The Common People, op. cit., p. 561.

${ }^{28} \mathrm{H}$. Pelling, A History of British Trade Unionism (Harmondsworth, 1963), p. 166. 
The first national conference of the unemployed movement was held in April 1921, the same month as the Sheffield conference at which the shop-stewards' movement was reconstituted. The similarity of names (National Unemployed Workers' Committee Movement and National Workers' Committee Movement) is obvious, and the governing body of both was named the National Administrative Council.

The unemployed movement retained its connections with the engineers throughout the years of its existence, as a result of the personal contacts between its members. There was no question of a Communist take-over at a later stage, since many of the early leaders of the unemployed became founder members of the CPGB. The link with Communism was thus present from the outset. The work of organising the unemployed appeared to develop a strong sympathy for Communism among those involved; it was felt that in Russia could be seen the alternative to the poverty and unemployment of capitalism. Moreover, since a large part of the CPGB membership was out of work in these years, it was only to be expected that the most active members of the unemployed movement would be Communists. However, whereas the National Workers' Committee Movement was merged with the British Bureau of the Red International of Labour Unions in June 1922, out of which the Minority Movement was launched specifically as a Communist front organisation in 1924, the unemployed movement was never formally committed to the party in any way. ${ }^{29}$

Nevertheless, at times the leadership of the NUWM was subject to Communist pressures. In 1930 the Fifth World Congress of the RILU condemned the NAC for "opposing the development of the N.U.W.M. into a mass organisation", and the movement was ordered to begin a more active recruitment campaign. ${ }^{30}$ Hannington and his colleagues responded to this call, and by the end of 1931 , as a result of the activities against the Means Test, membership had increased to 37,000. Six months previously it had been only 20,000. Early in 1931 Margaret McCarthy, for a time secretary of the Burnley Branch of the NUWM, went to Moscow to work in the Anglo-American section of the RILU, and drew up a report dealing with the weaknesses of the unemployed movement in Britain. ${ }^{31}$ Following this report, at the annual conference of the International in Prague in July 1931, a resolution was carried calling for the "development of mass activities and the building up of united front organisations on the broadest possible basis

29 Martin, Communism and the British Trade Unions, p. 33.

${ }^{30}$ H. Pelling, The British Communist Party (London, 1958), p. 64.

31 M. McCarthy, Generation in Revolt (London, 1953), pp. 151-63. 
at the labour exchanges", ${ }^{2}$ On 29 August 1931 the NAC issued a circular on these lines, instructing the branches to establish "unemployed councils" to which the unemployed could belong without needing to become members of the NUWM. The NAC subsequently devoted much time to the building of these councils, but with little success.

Communist party publications gave every support to the NUWM. The Communist Review, Sunday Worker and Daily Worker published frequent articles on the movement's activities, and often spoke with such authority on the tasks facing the NUWM that it was little wonder many of the Labour leaders saw the movement as merely another wing of the CPGB. ${ }^{33}$ Such suspicions were strengthened by the fact that the NAC generally followed the current party line fairly closely. After 1927, for example, the unemployed movement played a part in the policy of "class against class". The sixth national conference of the NUWM in 1929 resolved "to withhold our claim for affiliation to the TUC" in view of the "many grievous acts" the General Council had committed against the unemployed in general and the NUWM in particular. The seventh national conference, held at Bradford in February 1931, was devoted almost exclusively to attacks on the Labour Party Executive, the Labour Government and the TUC General Council. ${ }^{34}$

The NUWM's attempts to construct broad unemployed councils were closely allied to the change in Communist International tactics, away from the policy of sectarianism. By April 1933 the movement had completely reversed its earlier attitude of hostility to the TUC, and was declaring its "readiness to meet representatives from the General Council" to discuss the steps necessary for the "building of the United Front" against unemployment. ${ }^{35}$ The General Council rejected this approach, as it had done with that of the CPGB itself in March. Nevertheless, the NUWM persisted, and, following a resolution passed at its ninth national conference in December 1934, the NAC once more wrote to the TUC urging the development of United Front activity. General Secretary Citrine replied: "Acting under instructions, I have to inform you that I cannot, in future,

32 Communist Review, December 1931; Report of the National Administrative Council of the NUWM, July 1931, $16 \mathrm{pp}$. Copies of the NAC reports are held in the University of Hull Library.

${ }^{33}$ See for example Communist Review, December 1931 and February 1932; International Press Correspondence, 4 May 1934; Labour Monthly, May 1932.

34 Report of the Sixth National Conference of the NUWM, 1929, 25 pp.; Report of the Seventh National Conference of the NUWM, 1931, 24 pp. Available at the University of Hull Library.

${ }^{35}$ How to Fight Unemployment: Report of the Eighth National Conference of the NUWM, 1933, 20 pp. 
reply to communications from your organisation."36 Undeterred, in September 1935 the NAC stated that the unemployed movement "is not opposed to the Labour Party and trade unions", but "will assist in every way possible [...] towards defeating the National Government" ${ }^{37}$ In due course, at the general election of 1936, the NUWM, like the Communist Party, urged its supporters to vote for Labour candidates.

There can be little doubt, therefore, that the CPGB exerted a good deal of influence over the affairs of the NUWM at a national level. After 1930, as unemployment increased, and as the effectiveness of the Minority Movement declined, the Communist Party attempted to extend its control. Hannington had been a part-time member of the Party's Political Bureau since 1923, and played a major role in the Minority Movement between 1924 and 1927, years which were relatively quiet for the unemployed movement. ${ }^{38} \mathrm{He}$ was elected to the Central Committee of the CPGB at its seventh congress in November 1929, and stood as a Communist candidate against Margaret Bondfield at the election of that year. Hannington, however, appears to have regarded the unemployed movement as his own "child" and, as far as his work in this field was concerned, party considerations were secondary to the immediate needs of the unemployed. In 1938 Hannington was excluded from the Central Committee for opposing a party ruling on the movement.

While the Communist Party liked to think that it exercised complete control over the affairs of the unemployed movement, the NUWM, unlike the Minority Movement, for example, was always able to retain some degree of day-to-day autonomy. It was not the pliant tool of the CPGB the right-wing Labour leaders saw it as being. In April 1923 the third national conference of the movement rejected a resolution calling for a United Front with the Communists. ${ }^{39}$ The ninth conference in 1934 passed a resolution repudiating "with the utmost emphasis" any suggestion that the movement was an "ancillary" or "auxiliary" of the CPGB. ${ }^{40}$ From the party point of view, the unemployed movement's main fault was that its leaders, both nationally and in the districts, tended to look upon the problems of the unemployed as their first duty, instead of trying to develop a mass movement for political ends, as the party wished them to do.

36 The Fight against Unemployment and Poverty: Report of the Ninth National Conference of the NUWM, 1934, 16 pp.; NAC Report, September 1935, 9 pp.

37 NAC Report, September 1935, 9 pp.

38 Martin, Communism and the British Trade Unions, p. 53.

39 L. J. MacFarlane, The British Communist Party (London, 1966), p. 126.

40 The Fight against Unemployment and Poverty, op. cit. 
The unemployed struggles, with their constant emphasis on higher scales of unemployment benefit and the ending of the Means Test, were a poor "front" for the spread of Communist revolutionary doctrine. Membership fluctuated continually, and the majority of the unemployed still looked towards the Labour Party for political guidance. The unemployed man's first ambition was to find a job, and until then to try to find a means to increase his unemployment benefit; in general, he was little concerned with the idea of revolution or the concept of "class war", and, while the Communist Party's aim was to gain control of the unemployed movement, and direct its activities into a political organisation aimed at the overthrow of capitalism, very few of the tens of thousands of unemployed drawn into the agitation went on to join the CPGB. In fact, few actually joined the NUWM; it is unlikely that the total membership ever exceeded ten per cent of those out of work, and more probably it was never more than one hundred thousand. Despite the wide suffering of the depression years, there was nothing to show that a large percentage of the population in Britain was ready to join extreme political movements, and the CPGB continued to be "a revolutionary party in a non-revolutionary situation". ${ }^{41}$

At the local level, the response to the leadership's instructions, particularly as far as the CPGB was concerned, left much to be desired. The main efforts of the NUWM, and its most important achievements, were at the branch level. Almost every branch had members who acted as the representatives of the unemployed before courts of referees and publicassistance committees, and, although few had any legal training, after studying the insurance regulations they became quite proficient in arguing the technicalities of different cases, so that many claimants had their benefit restored or increased as a result. The local leaders, even more than their national counterparts, were too much involved in the "mundane" problems of unemployment benefit, task work and the Means Test to give time to the spread of Communist doctrine. Even the tasks of recruitment and the regular collection of the penny-a-week subscription were largely neglected. Few calls from the NAC met with any great response from the branches, other than on the occasions of Hunger Marches.

The efforts made by the national leadership to create unemployed councils, and to draw employed workers into the struggles of the out-ofwork, for example, met with almost complete failure. The NAC of May 1932 recorded just this verdict, and noted also that in two cases, where an attempt to create an unemployed council had been made, the local branch, far from becoming the "fighting core" of the council, had collapsed and

41 MacFarlane, The British Communist Party, op. cit., p. 275. 
gone out of existence. ${ }^{42}$ In the same manner, in preparation for the 1932 Hunger March, there was no apparent response to the NAC's call for the branches to encourage sympathetic-strike action against the Means Test on the part of the employed. The day the marchers were to arrive in London, 27 October 1932, was to be a "National Day of Struggle", but the NAC subsequently reported that the movement had not realised the "tremendous extent of the response to the March" which had developed throughout the country, and, as a result, had failed to turn this response into "mighty demonstrations" to show the Government "the wide character of the mass movement against its starvation policy". ${ }^{43}$ At the NUWM's eighth conference in April 1933, a resolution was passed on the need for branches to improve their response to instructions from headquarters. This stated that the movement "must overcome the practice which is frequently found in many branches of simply meeting and attending to routine business". 44

Unlike the Minority Movement, the NUWM did not receive any money from the CPGB or from the Soviet Union. The unemployed movement's activities were financed solely by the weekly subscriptions of its members and by occasional street collections. ${ }^{45}$ Using the NAC and national-conference reports, it has been possible to construct an almost complete picture of the finances of the national headquarters of the NUWM in the ten years from 1926 to 1935. This reveals that the income of the headquarters, even at the height of the movement in the years 1931-33, did not exceed $£ 1,500$ per year, and that in earlier years it was considerably less, the worst year being 1927 when income amounted to less than $£ 500$. Only on rare occasions did the movement's bank balance exceed $£ 100$, while there were occasions when it was less than $£ 10$. In the period after 1933 the NUWM was increasingly in debt, largely as a result of the losses incurred by the fortnightly newspaper, the Unemployed Leader, publication of which was begun in 1932. Debts exceeded $£ 200$ at most times, while in 1935 the financial position was so acute that donations were called for (and the sum of $£ 122$ received) and a small loan (about $£ 44$ ) had to be secured in order to prevent the movement from going bankrupt. The NAC calculated that a sum of several hundred pounds was owed to headquarters by branches, and promised to wipe off fifty per cent of any outstanding amount if the branches would pay the other half.

\footnotetext{
42 NAC Report, May 1932, 14 pp.

43 NAC Report, September 1932, 19 pp., NAC Report, December 1932, 22 pp.

44 How to Fight Unemployment, op. cit.

45 Interview with Harry McShane, Scottish organiser of the NUWM, at the University of Hull, March 1969. A tape recording of the interview is held by the University Library.
} 
Local activities were also paid for by the weekly subscriptions of members. The branch kept a fixed proportion of the money collected in this way; a small amount was passed onto the district council, where such a body existed, and the remainder was sent to London. In theory, headquarters received about one fifth of the branch income from membership dues. Out of the money accruing to national headquarters, the salaries of the three full-time officials, Hannington, Sid Elias, the Chairman, and Emrhys Llewellyn, the Secretary, were paid. Each received about three pounds per week in the period 1929 to 1935. The expense of district-council members attending NAC meetings in London were paid by the council concerned, which meant that attendances were invariably irregular. The return rail fare of those who took part on Hunger Marches was paid out of money collected en route and during the stay in London. The sale of pamphlets and other literature was expected to cover the costs of printing. Local running expenses were much less, usually only involving the rent for a meeting-room and the occasional equipping of local members of Hunger Marches. Branch officials were unpaid part-timers.

While the Communist Party brought a good deal of influence to bear on the leaders and the policies of the NUWM, when the local situation is taken into account it is clear that the unemployed movement was not simply a subsidiary of the CPGB. The NUWM's connection with the party was much less formal, and compared more closely with that of the Left Book Club, formed in 1936, than with other Communist front organisations. Indeed, the unemployed movement and the Left Book Club have much in common in this respect, since it was scarcely necessary for the CPGB to try to manipulate either body, as the two organisations naturally leaned towards Communism. The party realised the value of both as a means of spreading its propaganda, while members of both joined the party on their own initiative. On the other hand, the NUWM and the Left Book Club gained from the party a group of active and experienced workers, and a large number of writers and speakers. In each case, while, in general, party branches had little direct association with either the unemployed movement or the Club, a number of local branches of the NUWM, and likewise a number of the Left Book Club's discussion groups, fell completely under Communist control. ${ }^{46}$

Nevertheless, the hesitancy of the Labour leaders in regard to the NUWM was not without justification. In the upsurge of sympathy for the

${ }^{46}$ See J. Lewis, The Left Book Club. An Historical Record (London, 1970), pp. 107-15; S. Samuels, "The Left Book Club", in: Journal of Contemporary History, I (1966), No 2, pp. 65-86. 
unemployed in the winter of 1934-35, at the time of the National Government's new unemployment-insurance act, and in the widespread United Front activity of 1936, the Labour leaders were worried that new recruits to the labour movement had no notion of what had gone before as far as the CPGB was concerned, and hence could not understand the reluctance to join the United Front. In turn, the NUWM could blame its earlier denunciations of the Labour leaders for their continued refusal to accord the movement official recognition.

In this unfortunate situation, it was the unemployed who suffered most. There can be no doubt that, in spite of the size and urgency of the problem, in the inter-war years the official labour movement was slow to act on behalf of those out of work. In Michael Foot's words, "whatever the reasons, the fact is indisputable. Official Labour was sluggish, wary and bureaucratically pedantic in providing leadership for the great protest against poverty and industrial decay." ${ }^{27}$ Having allowed the NUWM to be first in the field, the Labour Party Executive and the TUC General Council thereafter made little attempt to wrest the organisation of the unemployed away from that body. They might easily have done so. A large body of unemployed workers eagerly waited for a sign of sympathy from their elected Labour leaders which never came. Official Labour was even overshadowed in the task of educating the unemployed to take full advantage of their entitlements under the insurance regulations. NUWM activity in this area far outweighed the efforts of the Labour Party and the TUC, and, had it been left to the official labour movement, even more unemployed would have been discouraged by the Means Test from applying for relief than was actually the case.

The position of the British labour movement in the years after 1926 was not an enviable one. Trade-union leaders were confronted by the prospect of successive wage reductions, "where every hard-fought victory in mitigating the cuts bore the semblance of a defeat. Fighting a losing battle for their own members, they felt unable to shoulder heavy fresh responsibilities on behalf of the unemployed."48 Yet part of the failure of the Labour Party and the TUC to provide a viable alternative to the NUWM must also be put down to the former's obsession with the question of the leadership of the existing unemployed movement. Having decided that the NUWM was the Communist Party "in disguise", the Labour leaders went on to assume that all those who were prepared to take part in its demonstrations were militants, half-way towards joining the CPGB and beyond

47 M. Foot, Aneurin Bevan, I: 1897-1945 (London, 1962), pp. 158-59.

${ }^{48}$ Ibid., p. 158. 
the reach of the official movement. This was far from the case: many became caught up in the NUWM for lack of any other means of expressing their dissatisfaction with the conditions in which they were expected to live. Thus for many out of work at this time the position was even more unenviable. The NUWM promised the unemployed immediate action, but estrangement from the main stream of the British labour movement. The Labour Party and the TUC, on the other hand, offered respectability, but beyond that only a long wait until the next general election. 